\title{
Geochemical and Palynological Analysis in Assessing Hydrocarbon Potential and Palaeoenvironmental Depo- sition, North Iraq
}

Dr.Ahmed Asker Ahmed ,College of science - University of Al-nahrain ,Baghdad-iraq Amer S.Al-Gibouri , College of science-University of Al-Anbar-iraq

\section{Abstract}

Geochemical and Palynological analysis were carried out to assess hydrocarbon potential and palaeoenvironmental deposition for (27) core and cutting rock samples recovered from selected oil exploratory wells, Makhul-2 (Mk-2),Qarachuq-1 (Qc-1) and Qarachuq-2(Qc-2), TaqTaq-1(Taq-1), Butmah-15 (Bm-15), Ajeel-8 (Aj-8)and Jabal kand( Jk -1) ,encountered from Butmah Formation ( Lower-Middle Liassic), Sargelu Formation (Middle Jurassic ) and Naokelekan Formation (upper Jurassic ).The value of palynological analyses in the undertaken study is to resolve stratigraphic and palaeoenvironmental consequences of Jurassic Period in Iraq

, thus the profuse of plant cuticle of translucent phytoclast in the basin of deposition refers to proximal deposi tional environment due to their specific gravity of this type of plant cuticle , whereas the opaque organic matter produced either from highly oxidized environment or from forest fire residues could refer due to its light specific gravity to distal depositional environment that this type could transported far from the continents toward the aquatic environment . Recurring Type A Amorphous kerogen indicates Oil -Prone beside various amorphous types $(\mathrm{B}, \mathrm{C}, \mathrm{D})$ within Zagros Fold Belt. The specified palynomorphs recovered from palynological analysis declared so many indications to determine the potentiality of source rocks .Almost all slides shows spores and pollen, phytoclasts and amorphous organic matter. Extracted resins and pigments are indicating toxic environment of type II-III kerogen that generates oil with subordinate gas.Geochemical analysis can aid also 
the undertaken study by determination the Terrestrial origin and kerogen type II-III .Previously proved that all crude oils within this sub- basin is belong to family A (sourced from Middle Jurassic Sargelu Formation) nearby local basins of family B (sourced from U. Triassic Kurra chine, and Rhaetic Baluti Shale Formation). Jurassic Period is considered as a generative hydrocarbon rock unit by means of both optical and chemical approaches definitely in the Great Kirkuk region and surrounding areas in North Iraq. Meanwhile the current studies focused on the western desert as promising reservoirs related with hydrocarbon pathways from Mesopotamian Basin.

\section{Introduction}

Iraq is a major producing country

for oil and natural gas, according to current producing and evaluation and estimations. Various studies and debates focusing mainly to arrange the material of the detailed studies straight forward and set-up sufficient database capable in contributing to open new horizons in exploration and production operation. The technology used for exploration developed currently but it is still depend on visual kerogen analyses which are commonly done by microscopically examining or palynological slides. The visually determined proportions of different kerogen types can be used in conjunction with geochemical analysis, to better interpret the generating potential of source rocks (Batten, 1999).Visual data can be obtained more quickly and cheaply than chemical data. The data obtained is also important in reducing risk assessment, which current drilling operations failed to find either economic and reliable reservoirs, or due to misconception of data management which should be followed in exploration procedures, so transmitted light technology optical or visualized and chemical analyses, followed in the undertaken study is aimed to recognize potentiality of studied wells and to de- 
termine the environment of deposition, kerogen types, and the type of the source rocks, considering as the later steps in determination of hydrocarbon system of the region, so the consequences may lead to get accurate and dependable results , and better understanding to chemical reactions of sedimentary biogenic precursor material within Mesopotamian sedimentary basin accompanied with all reliable depositional environment (Pitman,2004) . Extracted palynomorphs are relatively well preserved, due to the rapid burial, but almost all other slides illustrate the bacterial activity that causes to decay the particulate organic matter and convert it to amorphous type within aquatic reducing environment. For most observer [Bertrand, 1893; Bertrand, 1897; Renault, 1899; Trager, 1924], however, it was syngentic product under the microscope ; it consist of light yellow to brownish gel containing sometimes abundant yellow bodies which were finally recog- nized as being derived from algae (Durand, 1980).

\section{Geologic setting}

The area of study shows intensive tectonism forming folded zone within Mesopotamian basin (Fig.1) (Pitman, et al, 2004) .In particular, Jurassic geologic conditions of the Arabian subcontinent resulted in deposition of the following ideal sequence of primary petroleum system elements: Thick oil-prone source rocks, extensive reservoirfacies, and excellent seals. 


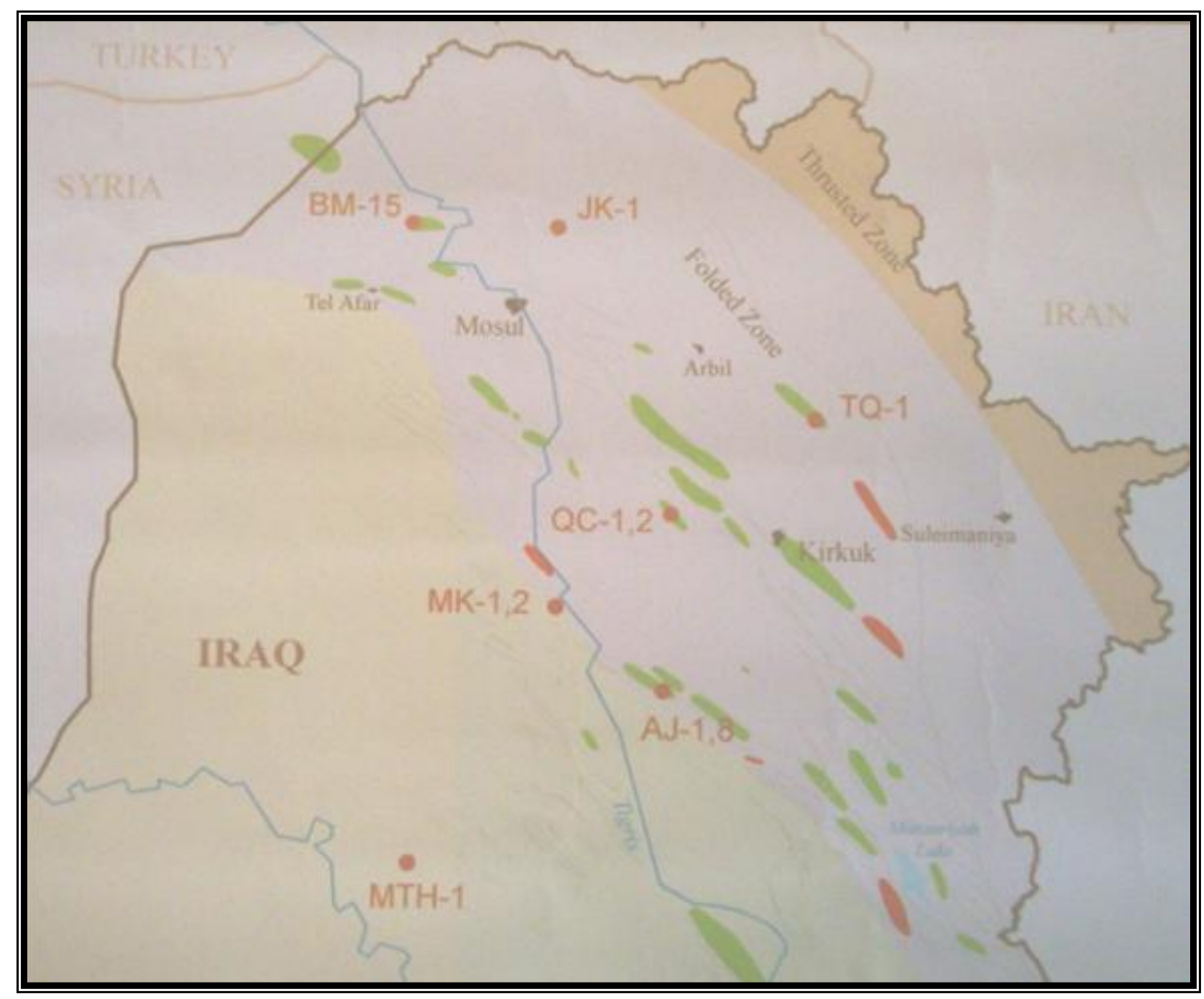

Legend

Oil field

Figure -1 Map shows the location of the studied wells.

Wide spread Early and Middle Jurassic marine transgression deposited a thick sequence of shallow marine shelf carbonates and platform evaporates. Late Jurassic (Oxfordian and Early Kimmeridgian) differential subsidence and sea level rise resulted in the formation of broad, intrashelf sub-basins, the intrashelf sub-basins were depocenters for the main Jurassic Petroleum System of the Eastern Arabian sub- 
continent, (Al-Husseini, 1997) recognized sedimentary organic matter. The lithology of the studied wells confirms the potentiality and

Naokelekan Fn.(1-4)

Sargelu Fn. (5-14)

Alan Fn. (15)

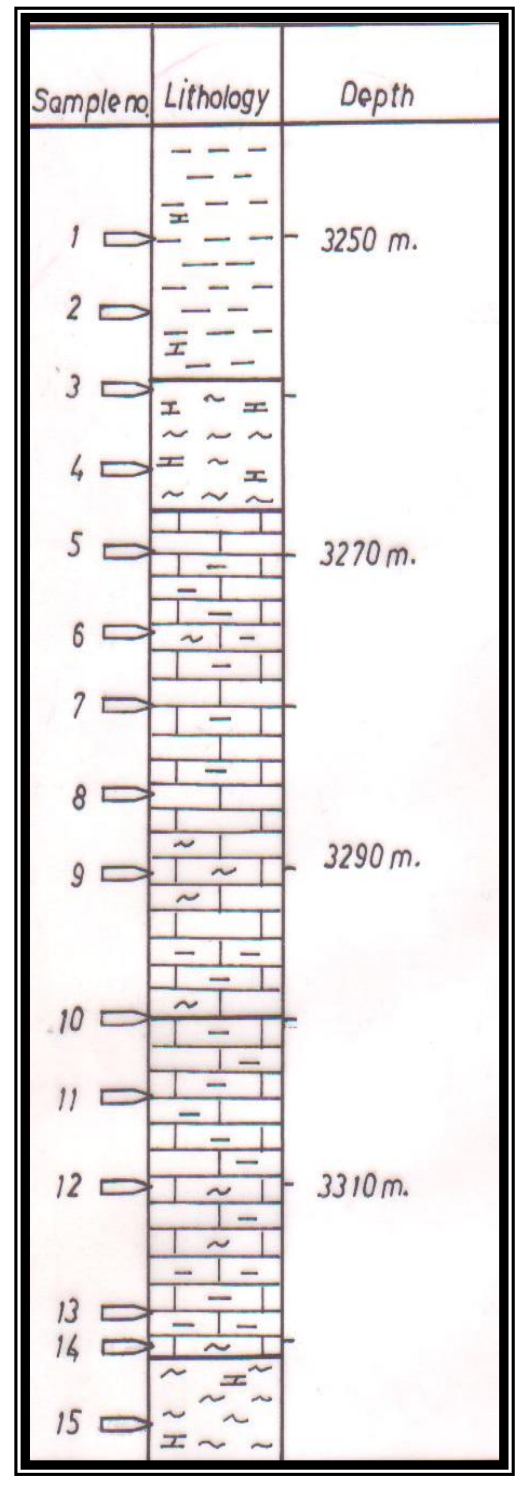

Aj-8
Sarmord Fn.(the up.part)

Sargelu Fn. (1-7)

Butmah Fn.(The lower part)

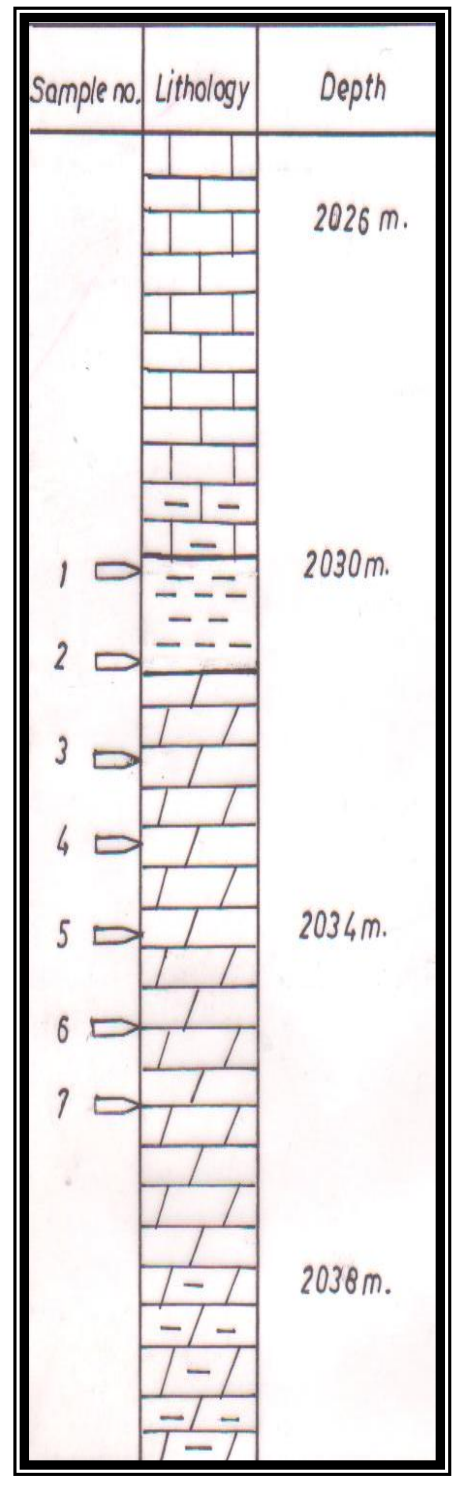

Bm-15
Naokelekan(1-4)

Sargelu Fn.(5-12)

Butmah Fn.(The lower part)

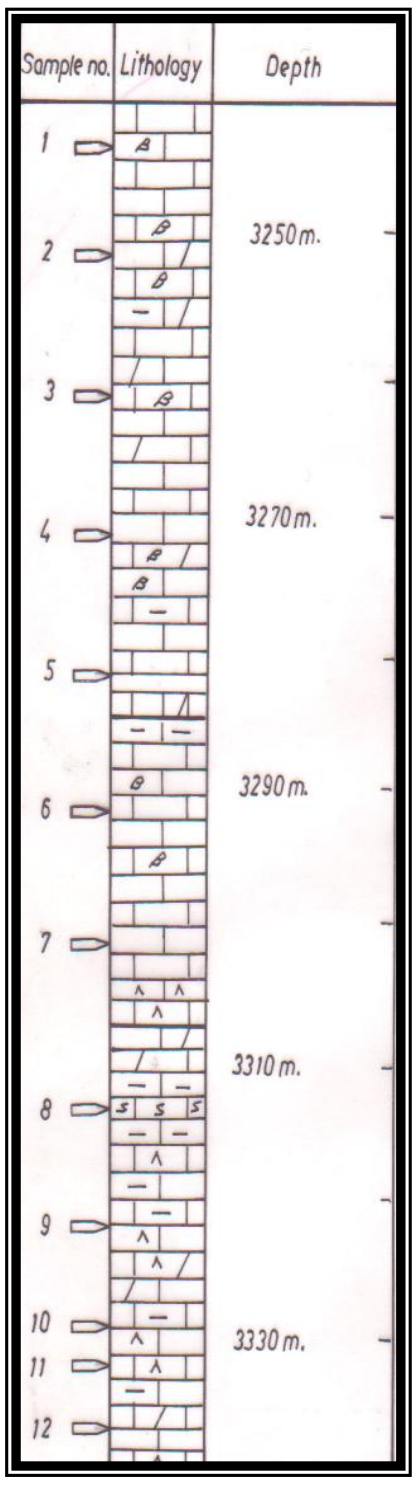

Taq-1 


\section{Journal of Petroleum Researches \& Studies $\quad \begin{gathered}2^{\text {No. }} .2 \\ \text { YEAR }\end{gathered}$}

Naokelekan Fn. (1-6)

Sargelu Fn. (7-15)

Butmah Fn. (16-19)

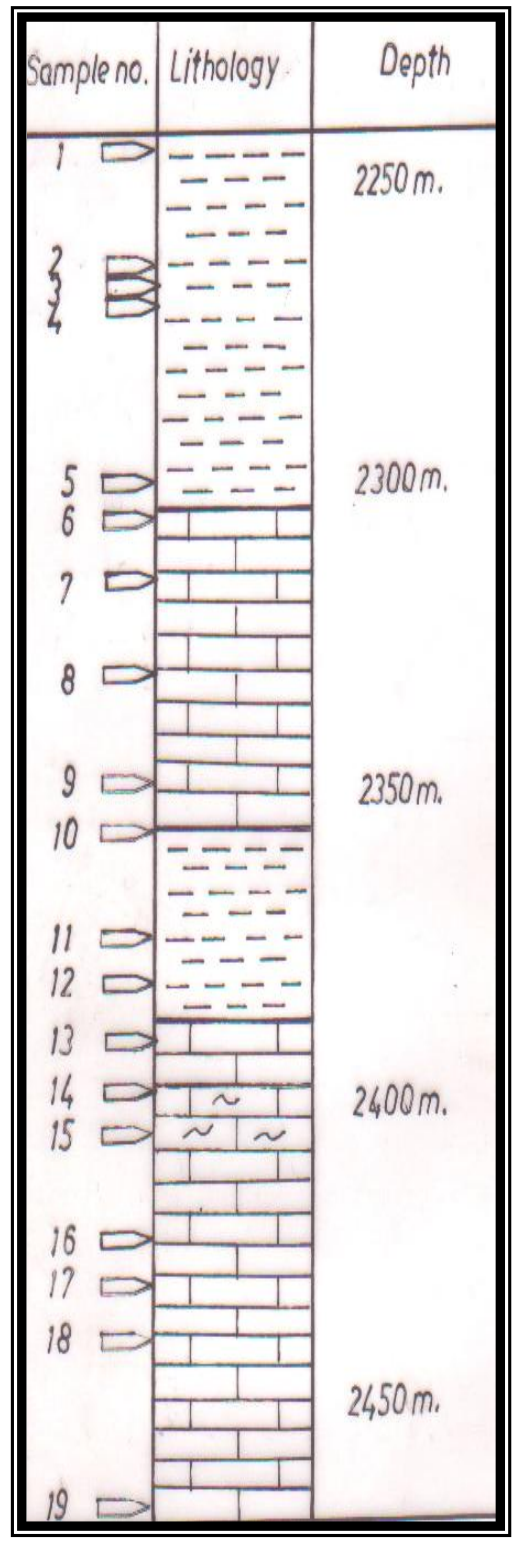

Mk-2
Naokelekan Fn. (1-4)

Sargelu Fn. (5-14)

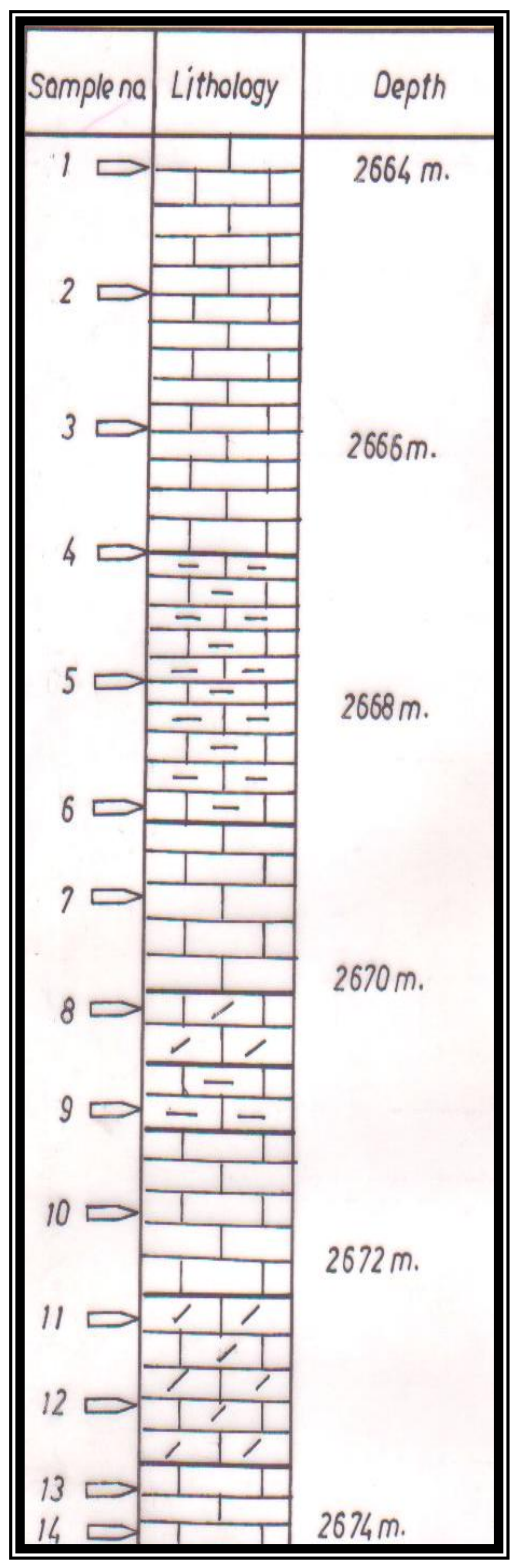

Qc-1
Naokelekan Fn. (1-5)

Sargelu Fn. (6-13)

Butmah Fn. (14-15)

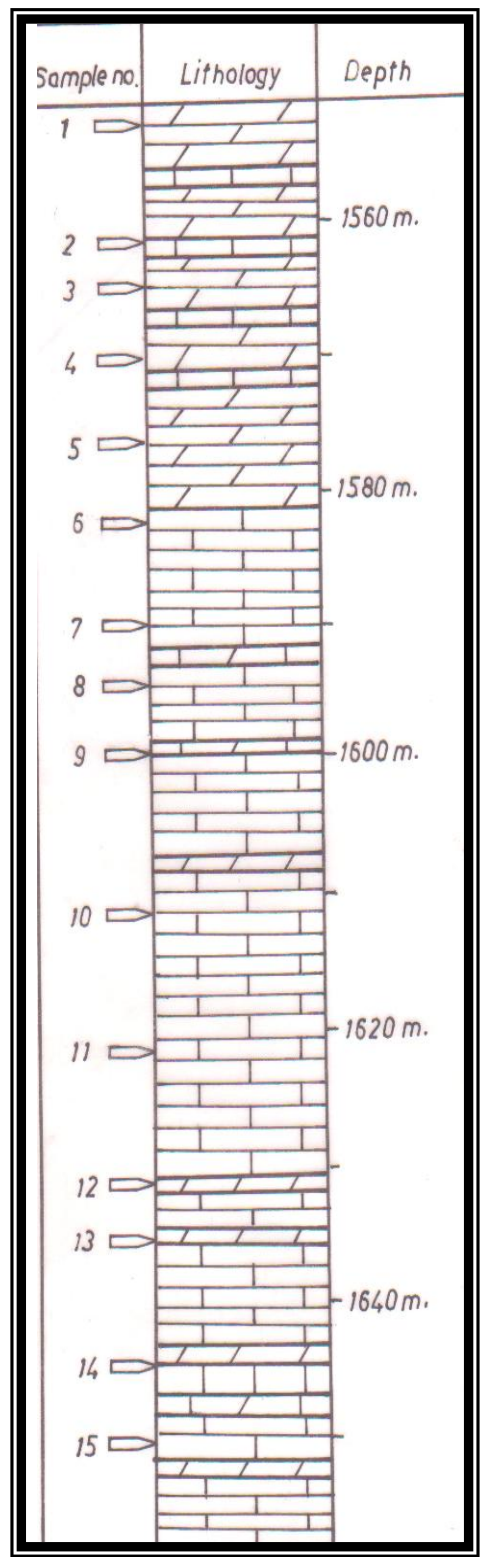

Qc-2

Fig-2 Samples recovered from encountered lithology of Early, Middle \& Late Jurassic age in the studied wells 


\section{Palynomorphs}

Kerogen may be classified into groups known as macerals, on the basis of morphology mentioned before decades but the most reliable one is by (Miles1994, Shimazaki1998 namely:

Type I (amorphous organic matter, alginite), very oil prone .usually marine

Type II (amorphous organic matter, exinite, cutinite, liptinite), oilprone. Lacustrine

Type III (higher plant debris, plant cuticle) mixed type, Terrestrial origin. Gas prone.

\section{I- Amorphous Organic Matter (HOM):}

Mixed type II-III (plate-1) is often called colloidal, algal, sapropelic or marine. For many people the term sapropelic is synonym for being derived from algae, although according to definition of Stachs, (1975) it designates a gel derived from organic debris which has putrefied in an anaerobic medium. Biopolymers produced from living things: carbohydrates, proteins, lipids, lignin and subgroups such as chitin, waxes, resins, glycosides, pigments, fats. some of these materials are consumed by burrowing organism, some may be complexes with mineral matter and some is attacked by microbes that use enzymes to degrade the biopolymers into simple monomers from which they were originally formed, some degraded biomonomers undergo no further reaction but others condense to form complex high molecular Asphaltens, Resins) weight geopolymers which, along with undrgraded biopolymers, become the precursors of kerogen (Hunt, 1995). Fig.4. n-alkane is the most sensitive to biodegradation and the higher molecular n-alkanes are easily disseminated through the initial stages of biodegradation. The typical exposure of amorphous kerogen is well distinguished in Jk-1, Taq1; Qc-1 shows chunky compact masses with mottled networks or weak polygonal texture, brownish color, sized (20-300) um, Type II-III 


\section{Journal of Petroleum Researches \& Studies}

kerogen which generates oil (Thompson et al, 1986).

\section{II- Macerals:}

Three types are distinguished:-

gin as macerals of the vitrinite family but have been altered of oxidized for

1- Macerals of Exinite family also called Liptinite generally containing spores and pollen, dinoflagellates, leaf cuticles, resin globules, debris, derived from Lipid-rich parts of higher plants. Spores and pollen is well identified in Jabal kand-1 at depth 2025m andQc-1 at depth $2673 \mathrm{~m}$, plate -2 .

2- Macerals of vitrinite family, gels derived especially from the lignocelluloses wall of cells from higher plants which is illustrated in (plate-3).

3- Macerals of inertinite family. These elements are generally of the same orivarious reasons such as reworking, change in redox conditions, the action of the microorganism, forest fires, etc. the domination of this type of Macerals defiantly in Taq-1, denote to the intensive tectonic activity nearby Foothills zone, the energy releases due to might forming the super giant Thermogenic dry and wet gas.

These fields is already distributed a long the Iraqi- Iranian border, Figure3 which is tectonically consider as the Frontier of Arabian shield collide with Eurasian Major shield. 


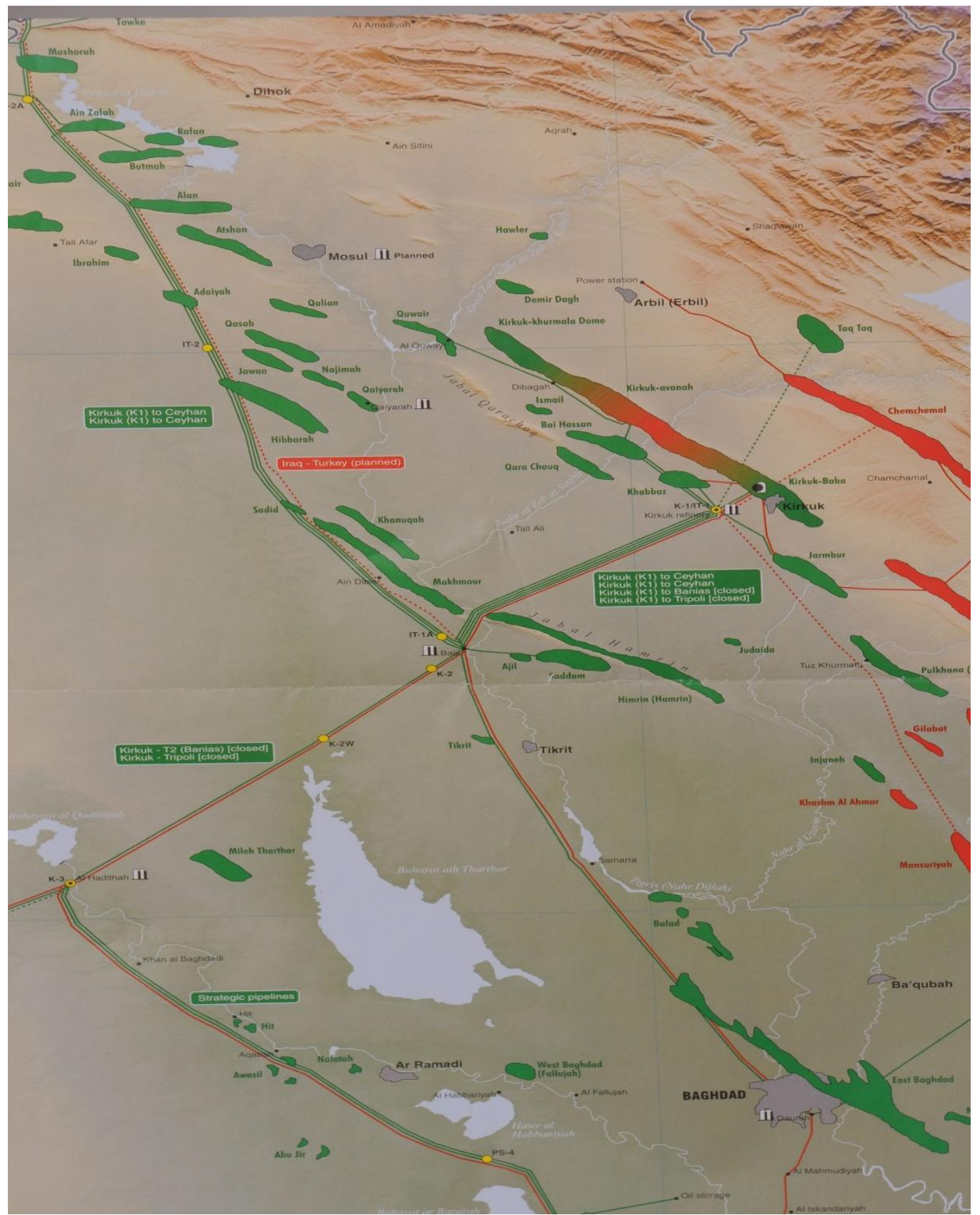

Figure -3 Oil and Gas Fields in Iraq (Chevron, 2009) 


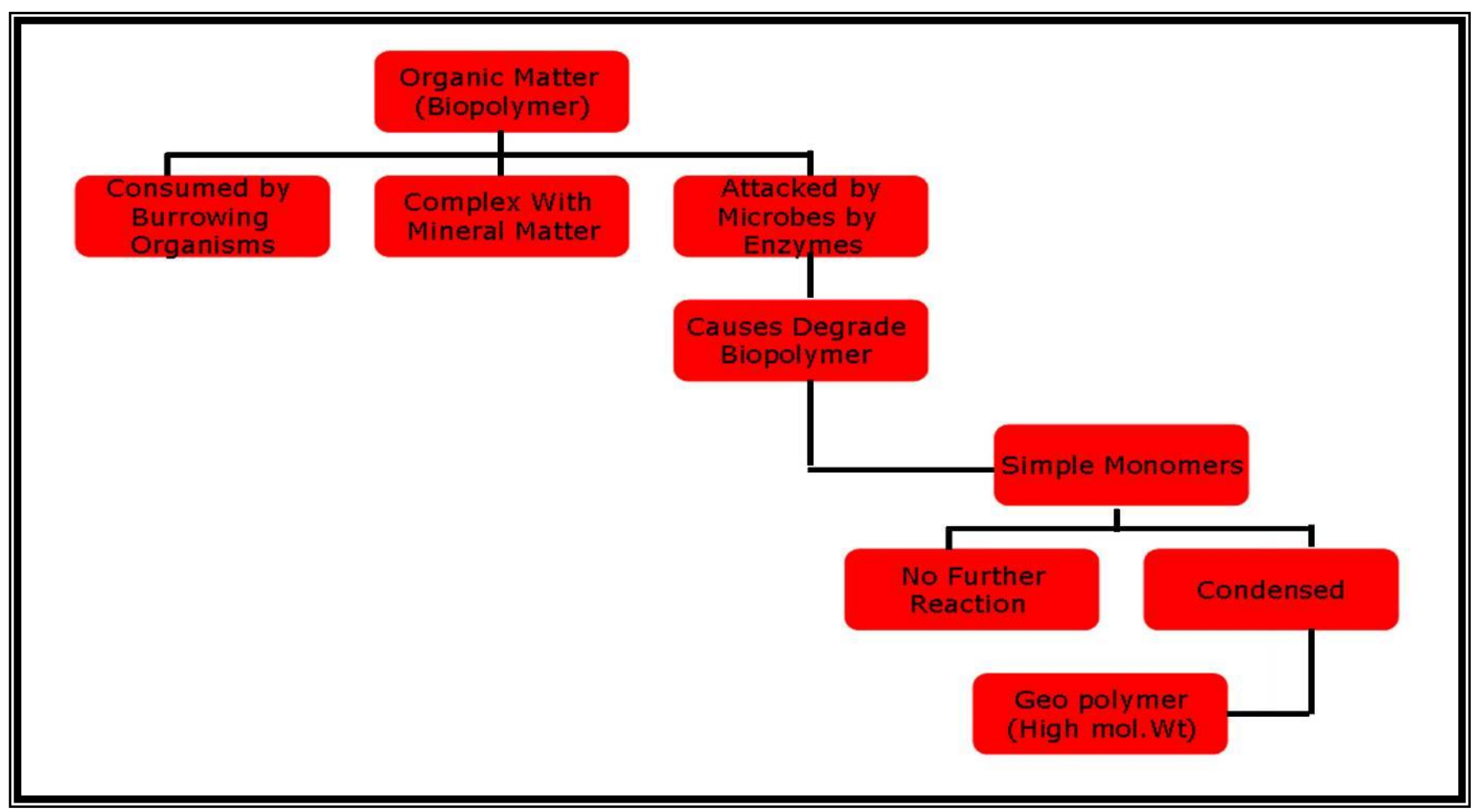

Figure -4 Initial Diagenesis Process

The deposited organic matter consists primarily of biopolymers from living things, carbohydrates, proteins, lignin, and sub groups such as chitin, waxes, resins, glycosides, pigments, fats and essential oils. Some of the material is consumed by burrowing organisms; some may be complexed with the mineral matter; and some is attacked by microbes that use en- zymes to degrade the biopolymers into simple monomers from which they were originally formed. Some degraded biomonomers undergo no further reaction, but others condense to form complex high- molecular -weight geopolymers, which, along with undergraded biopolymers, become the precursors of kerogen (Hunt, 1995). 


\section{Geochemical Analysis}

Chemical analyses of amorphous kerogen, with no optical description, do not clarify the issue. It is commonly considered to be dominantly algal in origin and thus equated with Type II or Type I kerogen .For this reason `Amorphous ` kerogen is considered to

Poor: less than $(0.5 \mathrm{wt} \%)$ TOC

Fair: $(0.5-1 w t \%)$ TOC

Good (1-2 wt \%) TOC

Very good (2-4 wt \%) TOC

Excellent more than (4 wt \%) TOC

Hydrogen and oxygen indices (Table 1) declared in figure-5 indicates the potentiality of the source rocks. have a good source potential for generating oil,( Tissot ,1984),(Al Ahmed,2006).

Total Organic Carbon (TOC) measures the quantity but not the quality of ganic carbon expressed as a percentage weight of the rock (Peters\&Cassa, 1994) as follows:-

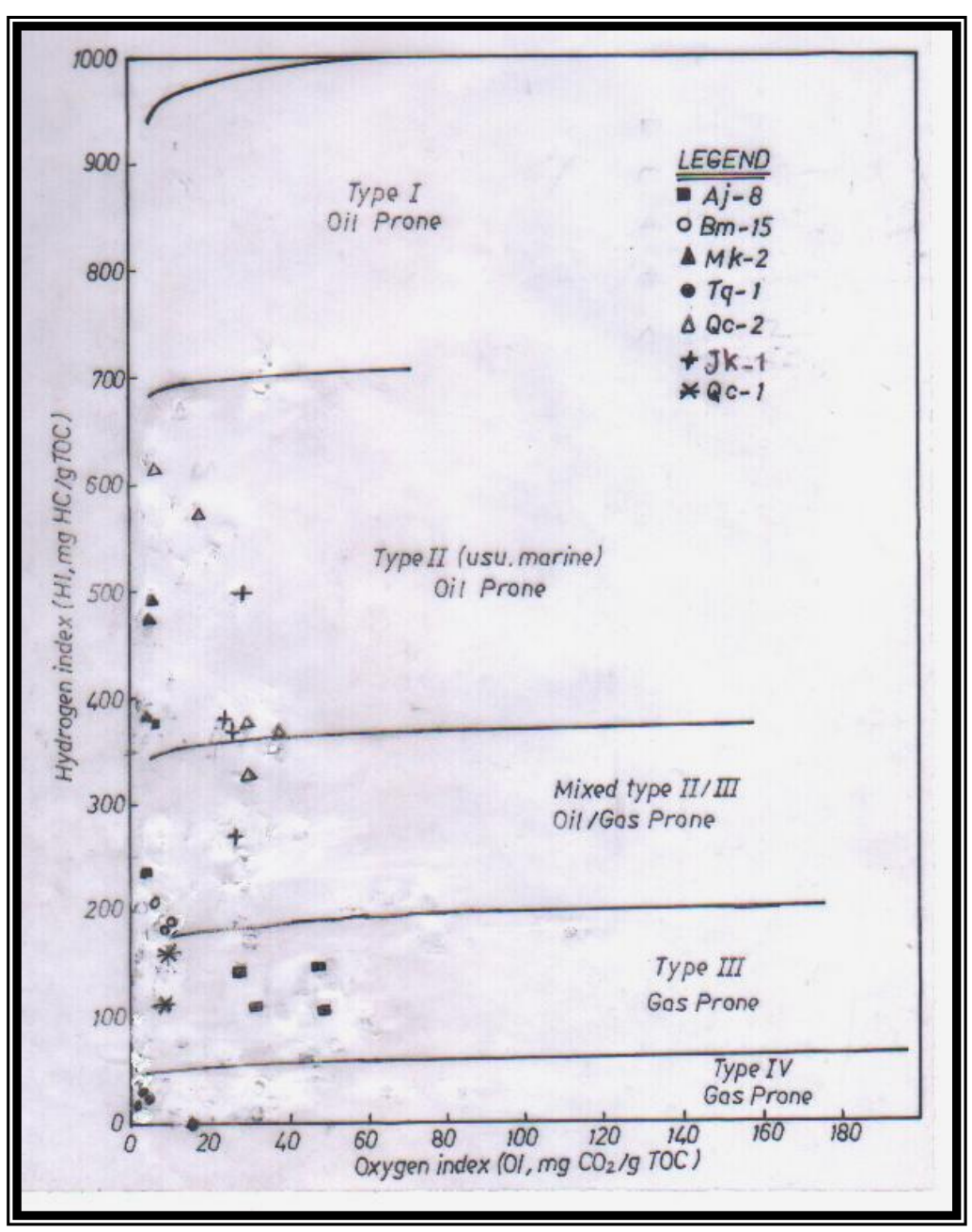

Fig 5: Kerogen types 


\section{Journal of Petroleum Researches \& Studies}

Table -1 Chemical analysis

\begin{tabular}{|c|c|c|c|c|c|}
\hline & Well name & Depth (m) & TOC & HI & $\overline{\text { OI }}$ \\
\hline $1-$ & AJ-8 & 3241 & 11.81 & 386 & 8 \\
\hline $2-$ & $=$ & 3248 & 10.20 & 265 & 8 \\
\hline $3-$ & $=$ & 3262 & 2.27 & 142 & 28 \\
\hline 4- & $=$ & 3300 & 1.26 & 142 & 49 \\
\hline $5-$ & $=$ & 3311 & 1.62 & 112 & 31 \\
\hline 6 & $=$ & 3320 & 1.09 & 106 & 50 \\
\hline $7-$ & $\mathrm{Bm}-5$ & 2030 & 2.07 & 189 & 13 \\
\hline $8-$ & $=$ & 2032 & 3.18 & 202 & 9 \\
\hline $9-$ & $=$ & 2036 & 1.70 & 185 & 11 \\
\hline $10-$ & Mk-2 & 2256 & 16.20 & 499 & 5 \\
\hline 11- & $=$ & 2258 & 19.77 & 479 & 3 \\
\hline 12- & $=$ & 2260 & 20.70 & 390 & 4 \\
\hline 13- & Taq-1 & 3244 & 7.53 & 21 & 5 \\
\hline 14- & $=$ & 3293 & 2.11 & 18 & 7 \\
\hline $15-$ & $=$ & 3304 & 2.02 & 1 & 4 \\
\hline 16- & $=$ & 3320 & 1.76 & 0 & 14 \\
\hline $17-$ & Qc-2 & 1567 & 1.12 & 356 & 36 \\
\hline 18- & $=$ & 1571 & 1.28 & 378 & 28 \\
\hline 19- & $=$ & 1612 & 1.00 & 323 & 28 \\
\hline $20-$ & $=$ & 1637 & 0.77 & 621 & 5 \\
\hline $21-$ & $=$ & 1651 & 0.50 & 572 & 18 \\
\hline $22-$ & Jk-1 & 2039 & 2.66 & 376 & 25 \\
\hline 23- & $=$ & 2057 & 1.84 & 493 & 28 \\
\hline $24-$ & $=$ & 2069 & 1.55 & 266 & 29 \\
\hline $25-$ & $=$ & 2082 & 2.24 & 368 & 24 \\
\hline $26-$ & Qc-1 & 2667 & 2.47 & 114 & 8 \\
\hline $27-$ & $=$ & 2670 & 6.79 & 166 & 7 \\
\hline
\end{tabular}




\section{Conclusion}

The most important conclusion from this work is establishment of useful visual kerogen observation which can aid in the prediction initially and quickly process of the hydrocarbon-generating potential of source rocks .The correlation of optically distinct amorphous kerogen types to the geochemically defined hydrocarbon -generating potentials ( oil prone -gas prone )in almost all great Kirkuk region that declares existing more than one palynofacies type referring to so many conclusions accordingly

1- The abundances of tremendous amounts of spores and pollen indicate terrestrial or continental paleo- deposition at the boundary or the marginal areas of the Lurstan basin defiantly around (Qc-1, Qc-2, Jk-1 and Bm-15). Thermal Alteration Index (TAI ) shows the color of the spores and pollen within the range( 2 to2+) Yellow- Dark yellow .

2- belonging to the chart established by(Staplin, 1969, Van Gejzel, 1982, Pearson, 1999 \& Mao et al, 1994) (fig.4) referring to peak oil generation at Aquatic suboxic-Anoxic environment
3- Phytoclasts (Translucent- Opaque matters) mainly obtained from wells located within great Kirkuk field. This field seems to be the major super giant gas field (Taq-1,Jk-1and Qc-1),indicated also of relatively various paleo depositional environment ,Jk-1 and Qc-1 refers to near shore according to the high specific gravity of the translucent phytoclast led to deposit initially ,otherwise opaque matters which are disperse off shore because of their light specific gravity which transport it for wide distances, defiantly around Mk-2 oil well and Taq -1 is either accumulated due to suboxic environment which is generating thermogenic (wet- dry gas) which exceeds in Temperature to above than $300 \mathrm{~F}$ to approximately depths about $18000 \mathrm{Ft}$, or due to forest fire .

4- Amorphous organic matter in this study refer to be of Type A, so it is of highly importance due to its optical characteristic to be an oil prone,

( Thomson and Demibicki, 1985)

5- Chemical analysis (TOC, HI, OI) which is performed on the samples shown in the 
table -1 , and the combination of optical and chemical techniques produce a very powerful method for understanding the hydrocarbon generating potential and origin of source rocks. 


\section{References}

1-Pitman, J.K., Steinshouer, D. and Lewan, M., 2004 "Petroleum generation and migration in the Mesopotamian Basin and Zagros Fold Belt of Iraq result from a basin modeling study, Vol 9 No.4,Gulf Petrolink Bahrain p.41-72.

2- Batten, D.J.1999. Palynofacies analysis, in Jones, T.P.Rowe\&N.P. (eds) Fossil plant spores, modern techniques .Geological society, London, p194-198.

3-Durand, B.(1980)In "Kerogen" P.25 Editions

Technip 27 Rue Ginoux 75737 Paris.

4- Al-Husseini, M.I, (1977) "Jurassic sequence stratigraphy of the western and southern Arabia Gulf; GeoArabia, V.2, P.361-382.

5-Stach's Text book of coal petrology, $2^{\text {nd }}$ Ed, Borntraeger, 1975.

6-Hunt, J.M, (1995)."Petroleum Geochemistry and Geology W.H.Frand company, 743pp, New York.

7-Thomson,C.L, Dembicki, H.j(1986)."Optical characteristics of amorphous Kerogens and the hydrocarbon-generation potential of source rocks Int. Journal of Coal Geology V.6, P229-249.

8-Tissot BP, Welte DH, (1984) Petroleum formation and occurrence, $2^{\text {nd }}$ edn. Spinger, Berlin Heidelberg, New York, 699pp.

9- Peters, K.E., and M.R. Cassa, (1994) Applied source rock geochemistry. In L.B. agoon and W.G. Dow (eds.) the petroleum system-form source to trap. AAPG, Memoir60.Tulsa: AAPG, PP.93-120.

10-Al Ahmed A.A, 2006" Organic geochemistry, Palynofacies and hydrocarbon potential of Sargelu Formation (Middle Jurassic) N. Iraq. pp120 (Unpublished $\mathrm{PhD}$ Thesis). 


\section{Plate -1}

Amorphous Organic Matter

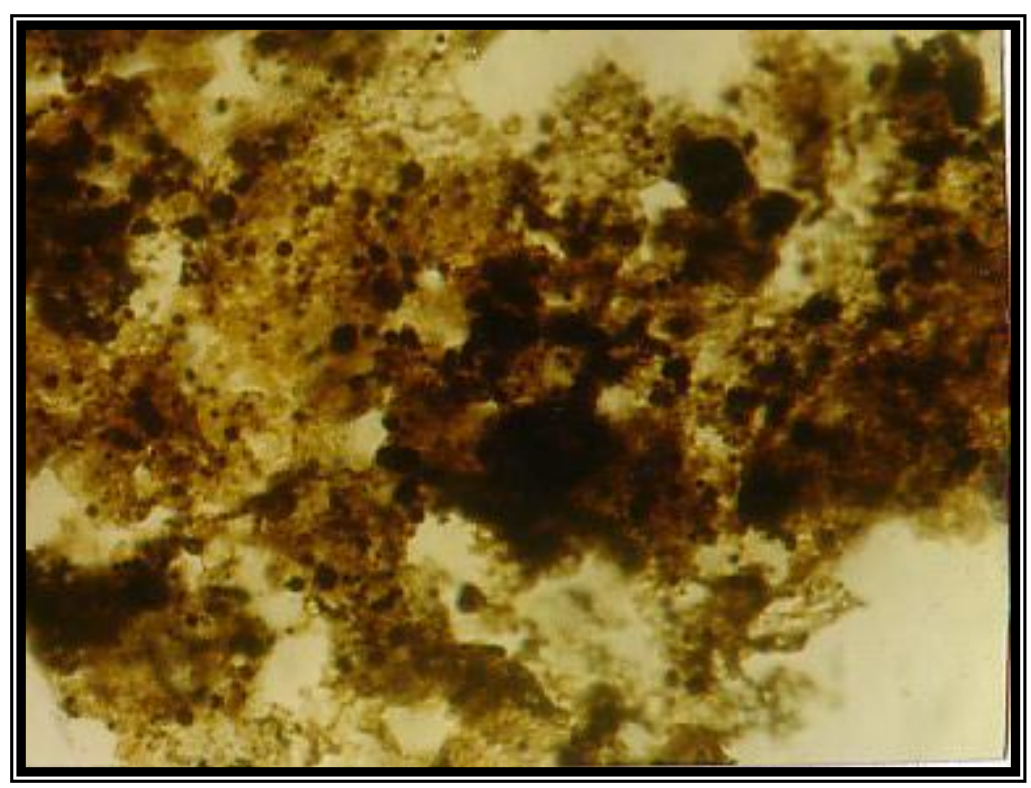

Well: JK-1

Depth: $1589 \mathrm{~m}$

Mag: $\times 250$ Type :A

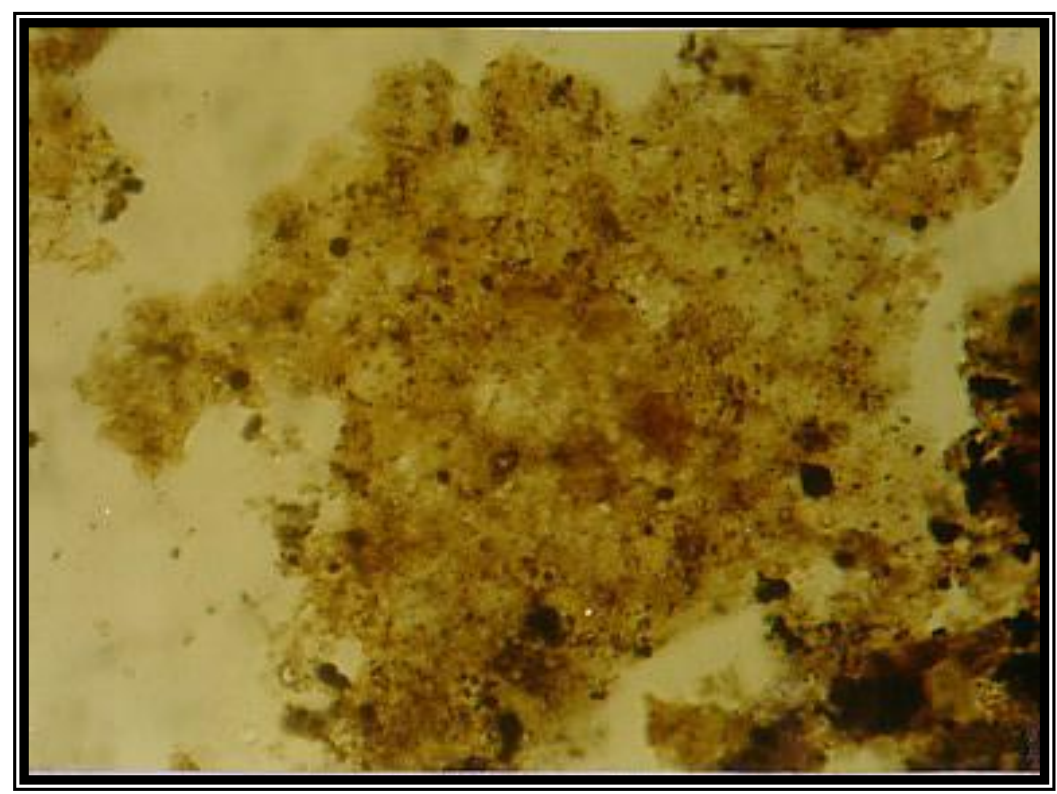

Well: Qc-2

Depth: $1589 \mathrm{~m}$

Mag: $\times 250$ Type :A 
Plate - 2

Spores and pollen

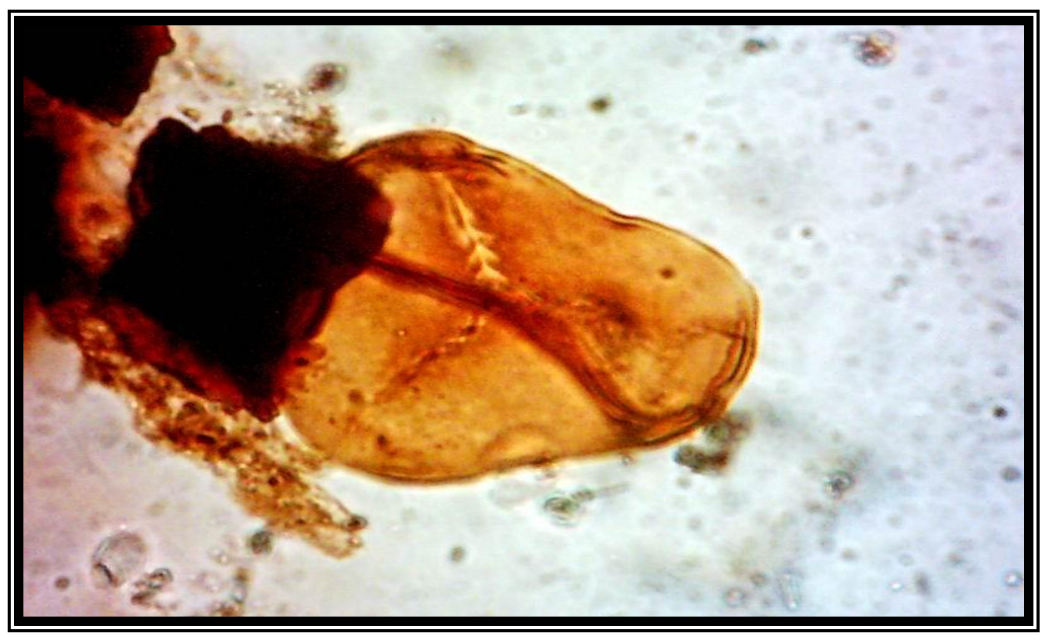

Well : JK - 1

Depth : $2025 \mathrm{~m}$

Mag : x800 (TAI : 3)

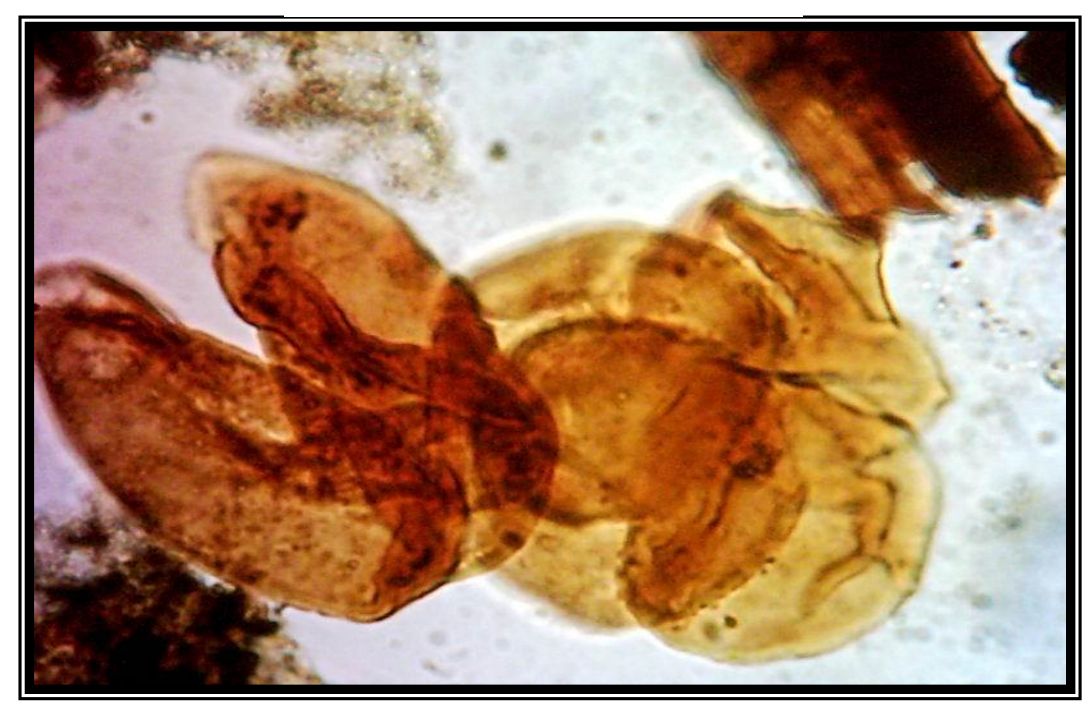

Well: Qc-1

Depth: 2673m

Mag: $\times 800$ (TAI: $3^{-}$) 
plate -3

Vitrinite

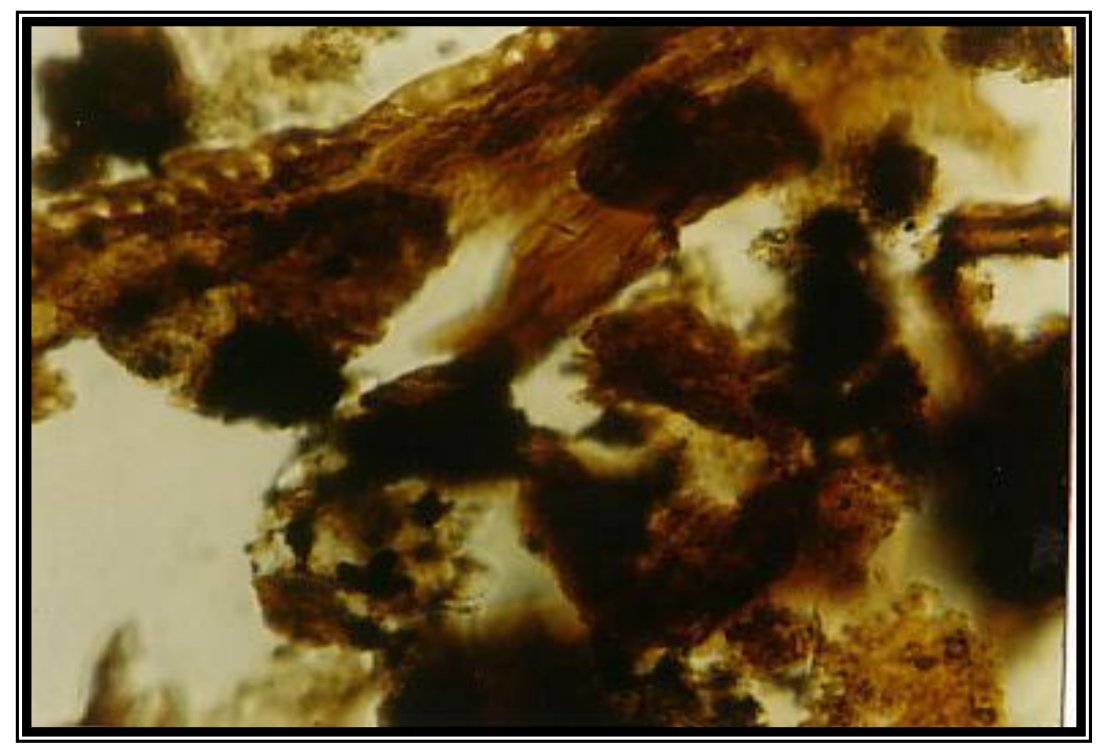

Well : JK - 1

Depth : $2037 \mathrm{~m}$

Mag.x400

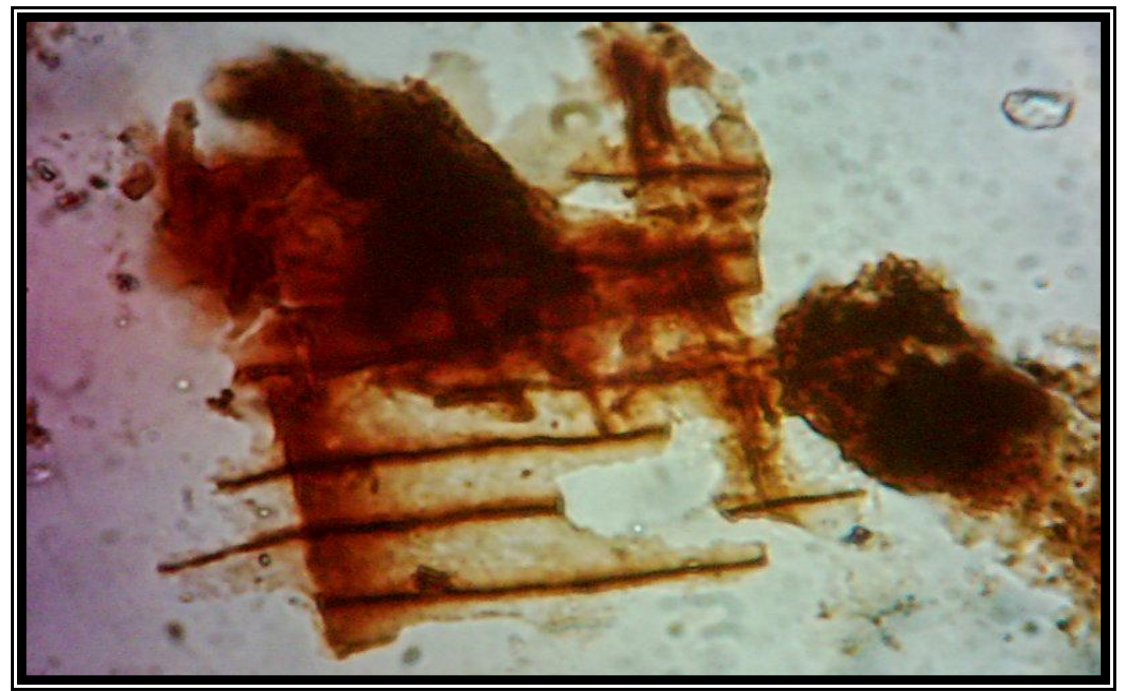

well : JK - 1

Depth : 2025 m

Mag.x400 


\section{$\underline{\text { Curriculum Vitae }}$}

Full name: Ahmed Asker Najaf Ahmed

Job title: Lecturer of petroleum Geology, Environmental pollution \& Engineering geology

Place and date of birth: Kirkuk/Iraq 1957

Address: Faculty of Science -University of Al-Nahrain-Jadiriyha -

Baghdad - Iraq.

Qualification:

1. B.Sc. in General Geology (1981) University of Mosul - Iraq

2. M.Sc. in Palynology / Organic Geochemistry (2001) University of Baghdad - Iraq.

3. Ph. D in Petroleum Geochemistry (2006) University of Baghdad Iraq. 